\title{
ADULT EDUCATION IN BRITAIN
}

$I^{N}$ $\mathrm{N}$ opening a debate on adult education in the House of Lords on November 24, Lord Greenhill said there was a real increase to-day in the demand for adult education in Britain. There was, in spite of the expansion in publicly provided education, a still greater demand for advanced education, both technical, cultural and nonvocational, which we could not supply. He urged that additional accommodation, particularly in residential colleges, should be made part and parcel of Britain's normal provision of adult education. He was strongly supported by Lord Hill of Luton, who urged that this was one of the great tasks of to-day following the educational policies of the past twenty years. Those who sought adult education, in the sense in which the term was used by Lord Greenhill in opening the debate, must undergo a disciplined study under the guidance of a competent teacher. Television could play a part in providing this disciplined study only if other links could be created between the teacher and the taught. This would not be easy, but it would be worth while trying to take the fullest advantage of an immensely powerful medium of mass communication, without forgetting that the personality and power of the teacher were essential. Baroness Elliot of Harwood suggested that the adult education organizations should approach the question from a more modern point of view than in the past, seeking to introduce some modern ideas into the classes provided. She also suggested that the pamphlet on consumer education, recently issued by the Research Institute for Consumer Affairs, indicated exciting possibilities for the fusion of adult education and consumer education, starting from practical issues and indicating how adult education and consumer education could create the informed, self-respecting and 'concerned' persons whose influence could be so great on the mind of the society in which we lived.

Lord Chorley directed attention to three groups requiring support. First, there were the evening institutes, and the evening schools for technical education which had scarcely received the recognition they deserved; then there were the refresher courses which were becoming increasingly important in the professions and to which the Robbins Report devoted some attention; the third group was the movement for bringing up to date the adult population, as a whole, in regard to knowledge-without it the modern world was incomprehensible and the adult citizen could not play a proper part in society. Besides this there was the general cultural education mentioned by Baroness Elliot, and Lord Chorley also supported Lord Hill's remarks concerning the need for proper teaching. Lord Francis-Williams thought that, contrary to the views of the Pilkington Committee, establishment of a fourth television channel entirely devoted to education would be useful. He thought we should consider more carefully the possible development of local radio and television linked to the universities, particularly the new universities, which might join with the local education authorities and local adult education associations and possibly with some of the existing correspondence colleges for the purpose. Baroness Gaitskell also believed that this idea of a university of the air would be worth exploring and could be more effective if combined with correspondence courses. She hoped that the Government would put adult education high on its list of priorities in education.

Lord Geddes suggested that a less academic view should be taken of some of the features of adult education, that the Albemarle Report should be taken more seriously, and that adult education for the less intellectual part of the population should be linked with some of the social service activities. He suggested that more research should be encouraged into the causes of anti-social behaviour, and that in this connexion we might consider the possibility of non-military national service which would cover, under disciplined procedures, many facets of social service, such as aid to the old, hospital service, service in underdeveloped countries and agriculture.

Lord Aberdare, replying to the debate for the Government, pointed out that a good deal had already been done for adult education in Britain: grants to adult education had more than doubled in the period from $1954-55$ to $1964-65$ and the number of full-time posts had increased from 254 to 311 ; he also directed attention to what had been done in sound broadcasting in the field of adult education.

\section{MUSEUM OF LONDON BILL}

$\mathrm{I}^{\mathrm{N}}$ $\mathrm{N}$ moving the second reading of the Museum of London Bill in the House of Lords on November 26, Lord Champion explained that the London Museum originated with the first Lord Harcourt, and was started in 1911 with private funds made available to form a collection of suitable objects. It soon succeeded in creating interest and attracting gifts and loans. King George $\mathrm{V}$ gave permission for the Museum to be housed in the State Apartments and other parts of Kensington Palace where the Museum was opened to the public in 1912. Kensington Palace was never intended to be more than a temporary home, and in 1913 Sir William Lever bought the lease of Stafford House and gave it to the Nation for the joint purposes of housing the London Museum and providing a setting for Government hospitality. The Trusteos of the London Museum then placed their collections at the disposal of the Government for the term of the lease of Stafford House, and as long afterwards as the collection should continue to be exhibited there or in some other equally suitable building maintained by the Government. The Government accepted these offers, and undertook financial responsibility for maintaining the London Museum, and from that time onwards the Trustees, apart from some ex officio ones, were appointed by the Prime Minister. The Museum was accommodated in Lancaster House, as Stafford House was re-named, from 1913 until the Second World War when most of the collections had to be put into safe storage and Lancaster House began to be used for international conferences. In 1940 the original lease of the building expired and a new forty-twoyear lease was taken by the Ministry of Works from the Crown Estate. After the War the Government decided that the building would continue to be required for conferences and official hospitality and that another home would have to be found for the Museum. In 1949 King George VI gave consent for part of Kensington Palace again to be used by the Museum for a term of fifteen years from December 1950 , and this term has been extended by Queen Elizabeth for a further five years to 1970.

Guildhall Museum was founded by order of the Court of Common Council in 1826. The first contribution to the collections consisted of Roman and other antiquities found during the excavations of the foundations of the new post office in St. Martins le Grand. The original concept of the Museum was simply that of an adjunct to 
the Library where objects could be seen to illustrate books on the Library's shelves. In 1872, when the new Library wing was opened, the Museum was housed in the basement beneath it and opened to the public. It has continued to be closely integrated with the Library, and the Library Committeo of the Common Council is directly responsible for its administration. Since 1921 the Museum has been supported financially by the City of London Corporation. All the objects in Guildhall Museum are connected with the City, many of them consisting of archaeological material, including much that has boen unearthed in the course of excavations connected with the re-building of the City since 1946. Guildhall Museum has always been closely associated with the scientific examination of sites cleared for re-building, and it has been generally agreed that all objects found during excavation should be given to the Museum. During the past eighteen years the total number of specimens in the Museum has increased by more than fifty per cent. As a result of war and war-damage the Guildhall collection moved about, and eventually the exhibition, containing about 10 per cent of the collection, carre to rest in the Royal Exchange; most of the collection was left in store at Guildhall.

Like the London Museum, Guildhall Museum is thus still waiting for adequate accommodation in a permanent home. Both aro essentially local museums, although the London Museum obviously has a far more than local interest. From this situation arose the idea that the accommodation problem might be solved by bringing the two Museums together under one roof with the cost shared between the Treasury and the County Council and the City of London. The essence of the scheme is that the two Museums will be amalgamated to form a new Museum of London, housed in a new building to be erected for the purpose on a site in the City of London. The capital and running costs will be borne jointly and equally by the Exchequer, the City Corporation and the Greater London Council, which has agreed to accept the obligations entered into by the London County Council in respect of the project. The Museum will be managed by a board of eighteen governors, six being nominated by each of the throe authorities. An Interim Board of Governors was constituted on these lines in May 1962, and a Director and Deputy-director-designate were appointed and a firm of architects was invited to prepare a preliminary scheme and estimates. This scheme provides for the Museum building to be on six floors, arranged around a garden court, with its east side forming the base for a $200-\mathrm{ft}$. high office tower block which will be leased separately by the City Corporation and will be so arranged that some $19,000 \mathrm{sq}$. ft. of space can be made available for expansion of the Museum at a future date. The Bill provides for payment by the Treasury of a sum not exceeding $£ 150,000$ in respect to furniture and equipment, and for the staff of the Museum to be brought within the Corporation's superannuation scheme. Staff salaries will be determined by the Corporation after consultation with the Treasury and the Greater London Council.

\section{THE BATTELLE INSTITUTE, GENEVA}

$I^{\mathrm{N}}$ NDEPENDENT consultative and sponsored research in industry has long been established practice in the United States, perhaps more often than not on a commercial rather than a strictly professional scale, as has been the general tendency over the years in Britain, although to this latter traditional precept there are to-day some noteworthy exceptions successfully established in Britain.

The original aim of the founder of 'Battelle', Gordon Battelle (Battelle Memorial Institute, Columbus, Ohio), was ". . . to contribute to industrial development by disseminating and using scientific knowledge for purposes of discovery and invention, thereby furthering technical progress". Battelle now has three research centres, at Columbus, Frankfurt and Geneva, with six branch offices in Washington, Los Angeles, Paris, London, Madrid and Gothenburg. It has thus established active and regular relations with industrial and scientific centres, as well as Government authorities throughout the western world; its activities are spreading to some of the so-called developing countries.

A booklet entitled Ten Years' Research at the Battelle Institute, Geneva*, has recontly been published, marking the completion of ten years' work of this organization in Geneva; it presents a well-documented and illustrated picture of some of the many and varied activities of the * Ten Years' Research at the Battelle Institute, Geneva. Pp. 71. (Geneva:
Battelle Institute, 1964.) Copies are also obtainable from the Battelle Institute, Ltd., 15 Hanover Square, London, W.1.
Institute at this particular centre. It is described as "... an invitation to European industry to visit the Institute". The impact of this well-designed and profusely illustrated publication can scarcely fail to impress the reader with the scale on which the Institute operates not only at Geneva but also internationally. A selection of some of the important disciplines covered by this centre includes: economics; applied mathematics; semi-conductors (solid-state physies); electronic paramagnetic resonance; optics; ultra high-vacua; metallurgy and physical properties of materials; refractory ceramic materials; electrochemistry; physical processes of measurement and analysis; electrical engineering and electronics; mochanical engineering; industrial high polymers and petrochemistry; foodstuffs; pharmaceutical and phytopharmaceutical products; chemical engineering; and mathematics and theoretical physics. In connexion with some of these subjects there have resulted ". . a total of 252 inventions" in the past few years at Geneva, ". . . and 1,266 patent applications have been filed in different countries; 587 patents have so far been issued, 221 of them in countries where prior patentability studies are carried out".

The booklet includes 192 references to publications with which the work and staff of the Institute have been concerned in the course of the research projects referred to here. For obvious reasons much sponsored research is of necessity highly confidential as between client and the Institute: to this extent the full story of achievements of the Institute cannot be divulged.

\section{COSMOLOGY IN THE U.S.S.R.}

$\mathrm{T}$ HIS account sumrnarizes articles which have appeared in Priroda. A. (7. Nikolaev and P. R. Popovich $(1,1 ; 1963)$ provide photographs of the Earth's surface as seen from a sputnik. G. A. Skuridin (1, 3; 1963) discusses cosmic physics-the radiation belt of the Earth, interplanetary plasma, primary cosmic radiation, magnetic fields of the Earth and the Moon and short-wave solar radiation. V. V. Shuleikin $(4,53 ; 1964)$ gives an account 